Journal of Biotechnology and Strategic Health Research

\author{
Research Article / Araştırma Makalesi
}

http://dergipark.org.tr/tr/pub/bshr

\title{
Adıyaman İlinde İzole Edilen Mycobacterium Tuberculosis Kompleksi Suşlarının Ilaç Direnci Profilleri Ve Genotip Dağılımlarının Belirlenmesi
}

\author{
Determination of Drug Resistance Profiles and Genotype Distributions of \\ Mycobacterium Tuberculosis Complex Strains Isolated in Adryaman Province
}

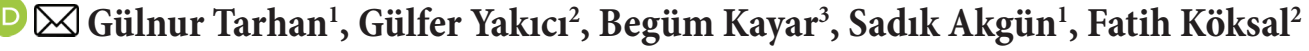

${ }^{1}$ Adıyaman Üniversitesi Tip Fakültesi Tıbbi Mikrobiyoloji Anabilim Dalı

${ }^{2}$ Çukurova Üniversitesi Tip Fakültesi Tibbi Mikrobiyoloji Anabilim Dalı

${ }^{3}$ Gaziantep İslam Bilim ve Teknoloji Üniversitesi, Tip Fakültesi Tibbi Mikrobiyoloji Anabilim Dalı

ORCID ID: Gülnur Tarhan, https://orcid.org/0000-0002-1019-0798, Gülfer Yakıc1, https://orcid.org/0000-0001-6486-3209,

Begüm Kayar, https://orcid.org/0000-0002-9657-5970, Sadık Akgün, https://orcid.org/0000-0002-1413-0450,

Fatih Köksal, https://orcid.org/0000-0003-0790-1525

${ }^{\star}$ Sorumlu Yazar / Corresponding Author: Prof. Dr. Gülnur Tarhan, e-posta / e-mail: gulnur.tarhan@yahoo.com

Geliş Tarihi / Received: 20-11-2020 Kabul Tarihi / Accepted: 13-12-2020 Yayın Tarihi / Online Published: 31-12-2020

Atıf Gösterimi/How to Cite: Tarhan G., Yakıcı G., Kayar B., Akgün S., Köksal F. Adıyaman İlinde İzole edilen Mycobacterium tuberculosis kompleksi suşlarının ilaç direnci profilleri ve genotip dağılımlarının belirlenmesi, J Biotechnol and Strategic Health Res. 2020;4(3):314-319

*Bu çalışma Adıyaman Üniversitesi Bilimsel Araştırma Projeleri Birimi tarafından TIPFMAP/2018-0001 nolu proje ile desteklenmiştir.

\begin{tabular}{|c|c|}
\hline \multicolumn{2}{|l|}{ Özet } \\
\hline Amaç & $\begin{array}{l}\text { Tüberküloz (TB) tüm dünyada ciddi bir problem olmaya devam etmektedir. Türkiye hala TB insidansı orta derecede olan ülkeler arasında yer almaktadır. Dünya Sağlık } \\
\text { Örgütü (WHO)'nün } 2019 \text { yll küresel verem raporuna göre, } 2018 \text { yıllında Türkiyede ki TB insidansı } 100.000 \text { 'de } 18 \text { dir. Bu raporda ülkemizde aynı yıldaki yeni ve yeniden } \\
\text { tedavi edilen olguların çoklu ilaç direnci (CCID) oranı \% 2,9 ve \% } 16 \text { olarak bildirilmiştir. Adıyaman ilinde izole edilen Mycobacterium tuberculosis kompleksi (MTBK) } \\
\text { suşlarına ait ilaç direnci profili ve genotip dağlımı hakkında veri bulunmamaktadır. Bu çalışma ilimizde izole edilen MTBK suşlarının direnç profili ve genotip } \\
\text { dağıllımının belirlenmesi amacı ile yapılmıştır. }\end{array}$ \\
\hline Yöntem & 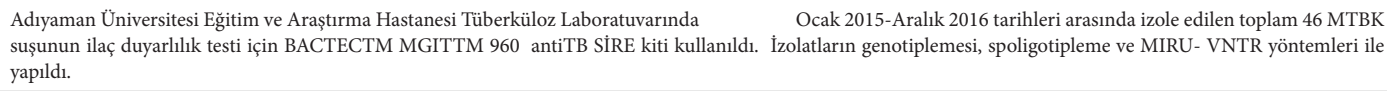 \\
\hline Bulgular & $\begin{array}{l}\text { Çalışmada incelenen } 46 \text { MTBK izolatı çoklu ilaca direnç oranı \%6,52 olarak saptandı. } 46 \text { izolattın } 37 \text { sinde } 6 \text { spoligotip ailesi saptanmıs olup, en fazla T ailesinde } \\
\text { kümelenme olduğu tespit edildi. MIRU sonuçlarına göre güncellenmiş bir veri tabanında mevcut MIRU uluslararası türleri ile eşleșen } 12 \text { orphan ve } 21 \text { pattern tanım- } \\
\text { landı. }\end{array}$ \\
\hline Sonuç & $\begin{array}{l}\text { Tüm dünyada önemli halk sağlı̆̆ı problemlerinden biri olan tüberkülozun kontrol altına alınmasında ve direncin en kısa sürede saptanmasında mikrobiyolojik çalış- } \\
\text { maların önemi büyüktür. Tüberkülozun kontrol altına alınması ve direnç durumunun belirlenmesinde mutlaka ilaç duyarlıllk testlerinin yapılması ve genotip düzeyin- } \\
\text { deki epidemiyolojik verilerin önemli bir yeri vardır. }\end{array}$ \\
\hline $\begin{array}{r}\text { Anahtar } \\
\text { kelimeler }\end{array}$ & Tüberküloz, Mikobakteri, Spoligotiplendirme, MIRU-VNTR \\
\hline \multicolumn{2}{|l|}{ Abstract } \\
\hline Aim & $\begin{array}{l}\text { Tuberculosis continues to be a serious problem in the world. Turkey is still among the countries with moderate TB incidence. According to the 2019 World Health Organization (WHO) } \\
\text { global TB report, in } 2018 \text { the incidence of TB in Turkey } 18 \text { cases per 100,000 people. Multi drug resistance rate of new and retreatment cases in 2013 was 0-2,9\% and } 12-29,9 \% \text { in } \\
\text { Turkey. There is no data on drug resistance profile and genotype distribution of Mycobacterium tuberculosis complex (MTBC) strains isolated in Adryaman. There was no previos data } \\
\text { for molecular epidemiology and drug resistance profile in Adiyaman province. This study was carried out to determine the resistance profile and genotype distribution of MTBK strains } \\
\text { isolated in our city. }\end{array}$ \\
\hline Methods & $\begin{array}{l}\text { Drug susceptibility testing of a total of } 46 \text { MTBK strains isolated in Adryaman University Training and Research Hospital Mycobacteriology Laboratory between January } 2015 \text { and Decem- } \\
\text { ber } 2016 \text { was performed using the BACTECTM MGITTM } 960 \text { TB drug sensitivity test SIRE kit. Isolates were genotyped by spoligotyping and MIRU-VNTR methods. }\end{array}$ \\
\hline Results & $\begin{array}{l}\text { Susceptibility testing to streptomycin, isoniazid, rifampin and ethambutol was also performed by MGIT } 960 \text { system by using SIRE Kit. Multidrug resistance was found as } 2.17 \% \text { among } \\
46 \text { MTBK isolates. In } 37 \text { of } 46 \text { isolates, } 6 \text { spoligotype families were detected, and it was found that there was clustering in the T family the most. In a database updated according to MIRU } \\
\text { results, } 12 \text { orphan and } 21 \text { patterns matching existing MIRU international types were identified. }\end{array}$ \\
\hline Conlusion & $\begin{array}{l}\text { Microbiological studies are of great importance in controlling tuberculosis, which is one of the important public health problems all over the world, and determining resistance as soon as } \\
\text { possible. Drug susceptibility tests and genotype epidemiological data have an important role in controlling tuberculosis and determining the resistance status. }\end{array}$ \\
\hline Key words & Tuberculosis, Mycobacteria, Spoligotyping, MIRU-VNTR \\
\hline
\end{tabular}




\section{GIIRIŞ}

Tüberküloz (TB), her yıl yaklaşık 8 milyondan fazla yeni olgu ve 2 milyondan fazla ölüme neden olan en önemli bulaşıcı hastalıklardan biridir. Tanı ve tedavilerinin iyileştirilmesi ile TB epidemiyolojisinin daha iyi anlaşılması; TB salgınlarını kontrol etmek ve yenilerinin gelişmesini engellemek için çok önemli koşullardır¹. Dünya Sağlık Örgütü (DSÖ)'nün 2019 yılı küresel TB raporuna göre, 2018 yılında Türkiye'de ki TB insidansı 100.000'de 18 dir. Ülkemizde 2018 yilında yeni ve yeniden tedavi edilen olgular arasında çoklu ilaç direnci (ÇİD) oranı sırası ile \% 2,9 ve $\% 16$ olarak saptanmıştır ${ }^{2}$. Moleküler epidemiyolojik incelemeler, geleneksel epidemiyolojik analizlere tamamlayıcı bir araç olarak giderek daha fazla kullanılmaktadır. Düzenli aralıklarla kümelenmiş kısa palindromik tekrar (CRISPR) lokusları, kümelenmiş Mycobacterium tuberculosis kompleksinin (MTBK) dünya çapındaki çeşitliliğini tanımlayan büyük "spoligotip" veri tabanları yayınlanmıştır ve MTBK 'nın yerel epidemiyolojik bulgularının küresel verileri ile karşılaştırılarak incelenmesine imkan sağlamıştır ${ }^{3-4}$.

Spoligotiplendirme ve 24 mycobacterial interspersed repetitive unit (MIRU)-variable-number tandem-repeat (VNTR) lokus analizinin birlikte kullanılması artık moleküler epidemiyolojide geleneksel IS6110-restriksiyon fragman uzunluğu polimorfizmi tekniğinin yerini almıştır ${ }^{5-7}$. Adıyaman ilinde moleküler epidemiyoloji ve ilaç direnci profiline ilişkin veri bulunmamaktadır. Bu çalışma, Adıyaman'da izole edilen MTBK izolatlarının spoligotiplendirme yöntemleri ve 24 lokuslu MIRU-VNTR ile genotiplendirme analizi yapılarak, moleküler epidemiyolojik profillerinin belirlenmesi ve bu modeller ile ÇİD-TB arasındaki olası bir ilişkinin analiz edilmesi amacı ile yapılmıştır.

\section{MATERYAL VE YÖNTEM}

Bakteri izolatları: Ocak 2015-Aralık 2016 tarihleri arasında Adıyaman Üniversitesi Eğitim ve Araştırma Hastanesi Tüberküloz Laboratuvarında izole edilen toplam 46 MTBK suşu çalışmaya dahil edildi. Her hastanın klinik örneğinden soyutlanan sadece bir izolat çalışıldı. Tüm izolatlar, spoligotiplendirme ve 24 mycobacterial interspersed repetitive units (MIRU) -variable-number tandem-tekrar (VNTR) yöntemi tiplemesi ile analiz edildi.

\section{Bakteriyolojik işlemler ve ilaç duyarlılık testleri}

Çalışmada incelenen bütün hastalara ait balgam örnekleri $\% 4 \mathrm{NaOH}-\mathrm{NALC}$ yöntemine göre dekontaminasyon-homojenizasyon ve konsantrasyon(DHK) işleminde sonra BACTECTM MGITTM 960 TB kültür sisteminde çalışıldı. MGIT tüplerinde pozitif saptanan örneklerin BD MGIT ${ }^{\mathrm{T} x}$ TBC İdentifikasyon Testi ile MTBK doğrulaması yapıldıktan sonra; üretici firmanın önerileri doğrultusunda streptomisin,isoniazid,rifampisin ve etambutol için antibiyogram testleri BACTECTM MGITTM 960 TB ilaç duyarlılık testi SİRE kiti ile yapıld1 $1^{8-9}$. Bu tüplerden aynı zamanda moleküler testler için Löwenstein Jensen (LJ) besiyerine alt kültürü yapılarak, belirgin koloniler oluşana kadar $37^{\circ} \mathrm{C}$.'de bekletildi. LJ besiyerinde üremiş kolonilerden steril distile su ile süspansiyon yapılarak moleküler testler için DNA izolasyonunda kullanıldı.

\section{DNA izolasyonu}

Bir öze dolusu bakteri kolonisi, 400 ul 1X TE (10 mM Tris, $1 \mathrm{mM}$ EDTA pH: 8) içinde süspanse edildi ve $80^{\circ} \mathrm{C}$ 'de 20 dakika inaktive edildi. Bakteriyel DNA, Mickle cihazında asitle yıkanmış mini cam boncuklar kullanılarak izole edildi.

\section{Moleküler tiplendirme testleri}

Spoligotiplendirme Isogen Bioscience kiti (Isogen Bioscience BV, Maarssen, The Netherlands) kiti kullanılarak, üretici firmanın önerdiği prosedürlere göre Çukurova Üniversitesi Tip Fakültesi, Tibbi Mikrobiyoloji Anabilim Dalı, Adana tarafından çalışıldı.

DNA konsantrasyonu spektrofotometrik olarak ölçüldü. Hedef bölgedeki doğrudan tekrarlar arasındaki mesafeler, 5 uçta biotinlenmiş Dra ve DRb primerleri kullanılarak 
amplifiye edildi. Amplifiye edilmiş DNA, ters çizgi blotlama ile M. tuberculosis H37Rv ve M.bovis BCG P3'ün spacer sekanslarından türetilen 43 immobilize edilmiş oligonükleotid setine hibridize edildi. Hibridize edici DNA'nın tespiti, geliştirilmiş kemilüminesans (ECL; Geliştirilmiş Kemo-Lüminesans Tespit kiti; Amersham, Little Chalfont, İngiltere) ve ardından üreticinin önerilerine uygun olarak X-ışını filmine (Hyperfilm ECL, Amersham) maruz bırakılarak yapıldı (Resim I). M. tuberculosis H37Rv ve M. bovis BCG P3 Pasteur suşu, spoligotipleme için referans suşlar olarak kullanıldı. Spoligotiplendirme sonuçları ikili formatta Excel elektronik tabloları olarak girildi ve Pasteur de Guadeloupe Enstitüsü’nün Dünya Spoligotype Veritaban1 (www.pasteur-guadeloupe.fr:8081/SITVIT_ONLINE) ile karşılaştırıldı $1^{10-14}$.
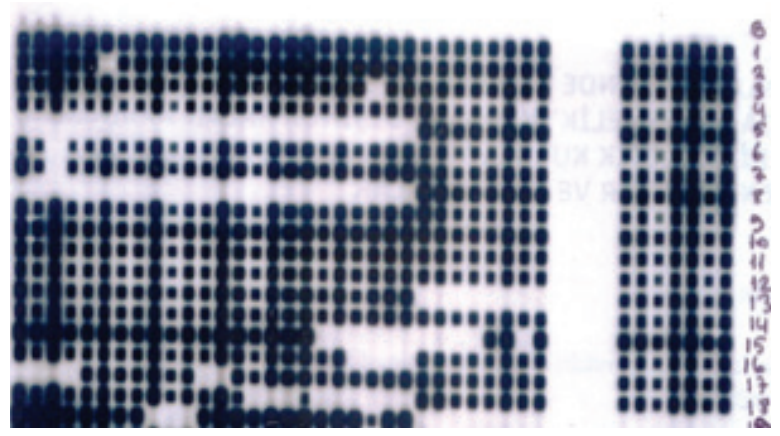

Resim I : MTBK izolatlarının spoligotipleme görüntüsü

MIRU-VNTR genotiplemesi, multipleks PCR, Rox etiketli MapMarker 1000 boyut standardı ve ABI 3100 ve ABI 3730-XL sekans cihazı kullanıldı. PCR fragmanlarının boyutlandırılması ve çeşitli VNTR allellerinin atanması, özelleştirilmiş GeneScan ve Genotyper veya Genemapper yazılım paketleri (PE Applied Biosystems) kullanılarak yapıldı. PCR karışımları, 96 oyuklu plaklar ve bir HotStartTaq DNA polimeraz kiti kullanıldı. PCR karışımı; 0.2 mM dNTP, PCR tamponu $2.5 \mathrm{mM} \mathrm{MgCl2,} 0.3 \mathrm{M}$ oligonükleotid ve $0.3 \mathrm{M}$ işaretlenmiş oligonükleotid kullanılarak hazırlandı. Her çalışmada pozitif ve negatif kontrol kullanıldı. PCR reaksiyonu $95^{\circ} \mathrm{C}$ 'de $15 \mathrm{dk}$ ön denatürasyon işleminden sonra; $1 \mathrm{~min}$ at $94^{\circ} \mathrm{C}^{\prime} \mathrm{e} 1 \mathrm{dk}, 59^{\circ} \mathrm{C} ' \mathrm{de} 1 \mathrm{dk}$ ve $72^{\circ} \mathrm{C}$ 'de $1 \mathrm{dk} 30$ sn 40 siklus olarak devam edildi. En son aşamada reaksiyon $72^{\circ} \mathrm{C}$ 'de $10 \mathrm{dk}$ bekletilerek gerçekleştirildi. Tüm primer setleri için aynı reaksiyon şartları kullanıldı. Amplifikasyon işleminlerinde pozitif kontrol olarak M. tuberculosis H37Rv, negatif kontrol olarak distile su kullanıldı. Kümeler, özdeş kombine MIRU-VNTR ve spoligotiplendirme paternleri gösteren MTBK ile enfekte hasta grupları olarak tanımland $1^{15-16}$.

\section{BULGULAR}

Bu çalışmada laboratuvarımızda izole edilen MTBK birinci kuşak antitüberküloz ilaçlara (streptomisin,izoniazid, rifampisin, etambutol) karşı direnç sonuçları Tabo 1'de verilmiştir.

\begin{tabular}{|l|c|}
\hline \multicolumn{2}{|l|}{ Tablo I: 46 MTBK izolatının ilaç duyarlılık test sonuçları } \\
\hline İlaçlar & Dirençli İzolatların Sayısı (\%) \\
\hline Streptomisin (S) & $5(10.86)$ \\
\hline İzoniazid (I) & $4(6.52)$ \\
\hline Rifampisin (R) & $4(6.52)$ \\
\hline Etambutol(E) & $2(4.34)$ \\
\hline S+I & $0(0.0)$ \\
\hline S+E & $1(2.17)$ \\
\hline I+R & $1(2.17)$ \\
\hline I+E & $2(4.34)$ \\
\hline S+I+R & $0(0.0)$ \\
\hline I+R+E & $0(0.0)$ \\
\hline S+I+R+E & $2(4.34)$ \\
\hline Toplam ÇİD & $3(2.17)$ \\
\hline Toplam & $15(32.60)$ \\
\hline
\end{tabular}

Buna göre 46 izolatın 31'i ( \%67.39) 4 majör ilaca duyarlı, 15’i (\% 32.60) en az bir ilaca dirençli bulunmuştur. Dirençli izolatlar arasında yapılan değerlendirmede; 15 izolat bir ilaca dirençli (\%32.60) iken 4’ü iki ilaca (\%8.69) idi. İncelenen izolatlar arasında üç ilaca direnç birlikte saptanmad. 2 izolat 4 ilaca da dirençli (\%4.34) bulundu. 46 MTBC izolatı içinde çoklu ilaca direnci \% 2.17 olarak saptandı.

Spoligotiplendirme yönteminde 46 izolattan 37'sinde test için tanımlayıcı sonuç alındı. İncelenen 37 izolat arasında 6 spoligotip ailesi tespit edildi. Bu çalışmada Beijing aile- 
sine rastlanmadı. Sonuçlarımız dünyadaki spoligotip veri bankası ile karşılaştırıldı̆̆ında; 6 grup oluşturan 37 izolattan 23 izolat T1, 5 izolat LAM7TUR, 3 izolat LAM7, 3 izolat H3, 2 izolat EA15 ve 1 izolat Tclade spoligotip ailesi içerisinde yer almıştır (Tablo 2).

\begin{tabular}{|l|c|c|c|c|}
\hline \multicolumn{6}{|l|}{ Tablo 2: } & MTBK İzolat kümelerinin spoligotipleri \\
\hline $\begin{array}{l}\text { Küme } \\
\text { Düzeni }\end{array}$ & $\begin{array}{c}\text { Küme } \\
\text { Büyüklügü }\end{array}$ & $\begin{array}{c}\text { İzolatların } \\
\text { Yüzdesi }\end{array}$ & $\begin{array}{c}\text { Octal } \\
\text { Kod }\end{array}$ & $\begin{array}{c}\text { Spoligotip } \\
\text { ailesi }\end{array}$ \\
\hline A & 5 & 13.51 & 777777404760771 & $\begin{array}{c}\text { LAM7- } \\
\text { TUR }\end{array}$ \\
\hline B & 23 & 62.16 & 777777600760771 & T1 \\
\hline C & 3 & 8.10 & 747767777700771 & H3 \\
\hline D & 3 & 8.10 & 777777474760771 & LAM7 \\
\hline E & 1 & 2.70 & 777777637760771 & Tclade \\
\hline F & 2 & 5.40 & 547727737400771 & EA15 \\
\hline
\end{tabular}

MIRU sonuçlarına göre, güncellenmiş bir veri tabanında mevcut MIRU uluslararası tiplerle eşleşen 12 orphan ve 21 pattern saptanmıştır

\section{TARTIŞMA}

Tüberküloz insan sağlığını tehdit eden enfeksiyon hastalıklarının başında gelmektedir. Etkili tedavi ve kontrol önlemlerine rağmen, çoklu ilaca dirençli bakteri kökenlerinin ortaya çıkması ve bunların duyarlı popülasyonda yayılmaya başlaması hastalığın tedavisi ve kontrol altına alınmasında önemli problemlere neden olmaktadır. Tüberkülozun kontrol altına alınmasında etkenin mikrobiyolojik tanısı altın standarttır. Doğru ilaç tedavi programlarının uygulanması için ilaç duyarlılık testlerinin yapılması krıitik önem taşımaktadır. Hastaların takip ve tedavisinin düzenlenmesinde; toplumdaki ilaç direnç oranlarının bilinmesi, buna ek olarak bireysel direnç durumunun saptanması önem taşımaktadır ${ }^{19-20}$.

Moleküler testlerin epidemiyolojik amaçlı kullanılması ile birlikte özellikle toplumda dolaşan kökenlerin bilinmesi, bulaş kaynaklarının tahmin edilmesi bakımından önemli aşamalar kaydedilmiş olup, bu çalışmalar tüberküloz kontrol ve tedavisinde yeni programların geliştirilmesine katkı sağlamıştır.

Çalışmamızda, ilimizde ettiğimiz 46 adet M.tuberculosis izolatının ilaç duyarlıık profili BACTECTM MGT TM 960 TB ilaç duyarlılık test ile belirlendi. İncelenen 46 izolatın 31'i ( \%67.39) dört ilaca (streptomisin, izoniazid, rifampisin, etambutol) duyarlı iken, 15’i (\% 32.60) en az bir ilaca dirençli bulundu. Dirençli izolatlar arasında yapılan değerlendirmede; 15 izolat bir ilaca dirençli(\%32.60) iken, 4’ü iki ilaca (\%8.69)dirençli idi. İncelenen izolatlar arasında üç ilaca direnç birlikte saptanmadı. 2 izolat 4 ilaca da dirençli (\%4.34) bulundu. İzoniazid ve rifampisine birlikte dirençli olarak 3 (\%2.17) izolat ÇİD olarak tanımlandı. Türkiye çeşitli bölgelerden ve dispanserlerden yap1lan çalışmaların analizinde, yeni hastalardan izole edilen tüberküloz basillerinde en az bir ilaca direnç oranının \% 18-26, ÇID MTB oranının \% 1.3-4.8; tedavi görmüş hastaların izolatlarında en az bir ilaca direnç oranının \% 28-53, ÇİD MTB oranının ise \% 4-17 arasında dağılım gösterdiği belirlenmiştir ${ }^{21}$. Ülkemizde direnç durumunu yansıtan en kapsamlı çalışmalardan biri, 1984-1989 ve 1990-1995 yılları arasında yapılmış 21 çalışma ve 27.959 kökenin sonuçlarını kapsayan bir meta-analiz çalışmasıdır. Bu çalışmaya göre 1984-1989 yıllarında toplam direnç oranları sırasıyla, STR (\% 22.5), RIF (\% 22.3), INH (\% 27.8) ve EMB (\% 7.8) olarak verilirken, 1990-1995 yılarında toplam direnç oranları sirasiyla, STR (\% 17.9), RIF (\% 22.1), INH (\% 23.8) ve EMB (\% 7.7) olarak belirtilmektedir ${ }^{22}$.

DSÖ’nün 2019 yılı küresel verem raporuna göre, 2018 y1lında Türkiye’de ki tüberküloz insidansı 100.000'de 18 dir. 2018 yılında yeni ve yeniden tedavi edilen olguların çoklu ilaç direnci oranı Türkiye’den \% 2,9 ve\% 16 olarak belirlenmiştir².

2018 yılında yeni ve yeniden tedavi edilen olguların çoklu ilaç direnci oranı Türkiyeden \% 2,9 ve \% 16 olarak saptanmıştır. DSÖ’nun “Küresel Tüberküloz 2018 Raporu”na göre ise Türkiye için 2017 yılında yeni ÇİD olgu oranı \%3,3 olarak belirtilmiştir ${ }^{24}$. Çalışmamızın yapıldığı dönemde 
Sağlık Bakanlığı’nca yayınlanan “Türkiyede Verem SavaŞ1 2017 Raporu"nda ülkemizdeki 2015 yılındaki direnç oranları INH için \%11,8; RIF için \%3,6; EMB için \%3,6; SM için \%10,3 olarak verilirken ÇİD-TB oranı \%2,5 olarak verilmiştir. Bu verilerde en yüksek direnç oranına sahip olan birinci seçenek anti-TB ilaç INH olarak belirtilmiş$\operatorname{tir}^{25}$. Çalışmamızda tek başına INH \%6.52 olarak saptandı. Çalışmamızdaki diğer birinci seçenek ilaç direnç oranları ile kıyaslandığında diğer çalışmalar ile uyumlu bulundu. Çalışmamızda ÇİD oranı \%2.17 olarak bulunmuştur. ÇİDTB saptanan 3 izolattan 2' sinin Çin, diğerinin Lübnan uyruklu hastalara ait olduğu belirlendi.

Tüberküloz çok bulaşıcı ve ilaç direnci yüksek bir hastalık olması nedeniyle daha iyi sürveyans programlarına ve hastalığın tanısının çok çabuk konulmasına gereksinim vardır. Suşlar arası epidemiyolojik açıdan coğrafik farklılıklar olduğu düşünülmektedir. Yapılan epidemiyolojik çalışmalarda farklı coğrafik bölgelerden izole edilen suşların biribiri ile kıyaslanması ve bireysel suşların izlenebilmesi tüberkülozun tüm dünyada geçiş yolları, yüksek virülans ve ÇİD-TB’le ilişkili suşlar saptanabileceğini düşündürmektedir. Moleküler yöntemlerin rutin kullanıma girmesiyle birlikte epidemiyoloji çalışmaları kolaylaşmıştır. Bakteri suşlarının tiplendirilmesi, tüberküloz prevalansı ve yayılımı çalışılan en önemli konuları oluşturmaktadır. Spoligotiplendirme, MIRU ve IS6110 yöntemleri ile yap1lan çalışmalarda M.tuberculosis izolatları duyarlı bir şekilde tiplendirilmektedir ${ }^{25-31}$.

$\mathrm{Bu}$ çalışmalardan elde edilen veriler sayesinde epidemiyolojik kökene göre hızlı bir şekilde tedavi protokollerinin oluşturulması ve hastalığın kontrol altına alınması planlanmaktadır. Çalışmamızda laboratuarımızda izole ettiğimiz 46 adet MTBK suşunun spoligotiplendirme ve 24 lokuslu MIRU yöntemleri ile epidemiyolojik kökenleri araştırıldı. 9 izolatta düşük DNA konsantrasyonu nedeni ile sonuç alınamadı. İncelenen 37 izolat arasında 6 spoligotip ailesi tespit edildi. Bu çalışmada Beijing ailesine rastlanmadı. Sonuçlarımız dünyadaki spoligotip veri ban- kası ile karşılaştırıldığında 6 grup oluşturan 37 izolattan 23 izolat T1, 5 izolat LAM7TUR, 3 izolat LAM7, 3 izolat H3, 2 izolat EA15 ve 1 izolat Tclade spoligotip ailesi içerisinde yer almıştır. Değerlendirmeye aldığımız 37 izolat içerisinde T1 suşlarının \%62,16 oranı ile en sık karşılaşılan aileyi oluşturdukları ve SpolDB4 database de bu ailenin 3 alt tipinin olduğu görülmüştür. MIRU sonuçlarına göre, güncellenmiş bir veri tabanında mevcut MIRU uluslararası tiplerle eşleşen 12 orphan ve 21 pattern saptanmıştır. Zeytinli ve ark.nın Çukurova bölgesinde ve Güneydoğu Anadolu bölgesini de içine alan geniş kapsamlı çalışmalarında tüberküloz tanısı amacı ile Adana ilindeki bölge tüberküloz laboratuvarına gönderilen akciğer tüberkülozlu hastalara ait örneklerden üretilen 467 MTBK izolatları ile yaptıkları çalışmada; spoligotiplendirme yöntemiyle 467 izolatta bölgede en yaygın görülen ailenin T1 ailesi olduğu (\%51.9) ve bunu LAM7 TUR ailesinin (\%11.5) izlediği belirtilmiştir. Spoligotiplendirme yöntemiyle değerlendirilen suşlar arasında, bölgede T1 ailesinin daha baskın olduğu tespit edilmiştir. Çalışmamızda elde ettiğimiz sonuç bölge verileri ile uyumluluk göstermiştir ${ }^{32}$.

Sonuç olarak, tüm dünyada önemli halk sağlığg problemlerinden biri olan tüberkülozun kontrol altına alınmasında ve direncin en kısa sürede saptanmasında mikrobiyolojik çalışmaların önemi büyüktür. Doğru tedavi protokollerinin oluşturulmasında mutlaka ilaç duyarlılık testlerinin yapılması ve genotip düzeyindeki epidemiyolojik verilerin enfeksiyon kaynağının tanımlanması ve kontrol önlemlerinin alınmasında önemli olduğu düşüncesindeyiz. 
J Biotechnol and Strategic Health Res. 2020;4(3):314-319

\section{Kaynaklar}

1. Türkiye’de Verem Savaș Raporu 2018. https://hsgm.saglik.gov.tr/tr/tuberkuloz-haberler/ turkiye-de-verem-savas-2019-raporu.html.

2. WHO. Global tuberculosis report 2019. Geneva: World HealthOrganization, 2020.https:// www.who.int/tb/publications/global_report/en/.

3. Mathema B, Kurepina NE, Bifani PJ, Kreiswirth BN. Molecular epidemiology of tuberculosis: Current insights. Clin Microbiol Rev 2006;19:658-685.

4. Kanduma, E., T. D. McHugh, and S. H. Gillespie. Molecular methods for Mycobacterium tuberculosis strain typing: a user's guide. J. Appl. Microbiol. 2003;94:781-791.

5. Peterson R. Molecular Epidemiology of Tuberculosis. Karolinska Institutet, Sweden, 2009.

6. Durmaz, R. Tüberkülozun Epidemiyolojik Arastırmalarında Laboratuvarın Yeri. 21.Yüzyılda Tüberküloz Sempozyumu. 11-12 Haziran, Samsun, 2003; 443-456.

7. Rodriguez NA. et al. Evaluation of the new advanced 15-loci MIRU-VNTR genotyping tool in Mycobacterium tuberculosis molecular epidemiology studies. BMC Microbiology 2008; 8: 34 .

8. Kubica G. P. W, Dye E, Cohn M. L, Middlebrook G: Sputum digestion and decontamination with N-acetyl-L-cysteine-sodiumhydroxide for culture of mycobacteria. Am. Rev. Respir. Dis. 1993; 87:775-780

9. BectonDickinson. MGIT For BACTEC ${ }^{\text {" }}$ MGIT $960{ }^{\text {"x }}$ TB System. 2006.

10. Roring S, Brittain D, Bunschoten AE, Hughes MS, Skuce RA, van Embden JD, et al. Spacer oligotyping of Mycobacterium bovis isolates compared to typing by restriction fragment length polymorphism using PGRS, DR and IS6110 probes. Vet Microbiol. 1998;61: 111-120. 10.1016/S0378-1135(98)00178-183.

11. www.pasteur-guadeloupe.fr:8081/sttvit_online.

12. www.isogen-lifescience.com.

13. Brudey K, Driscoll JR, Rigouts L, Prodinger WM, Gori A, Al-Hajoj SA. Mycobacterium tuberculosis complex genetic diversity: mining thefourth international spoligotyping database (SpolDB4) forclassification, population genetics and epidemiology, BMC Microbiology. 2006;6:23.

14. Sola C, Horgen L, Maisetti J, Devallois A, Goh KS, Rastogi N Spoligotyping followed by double-repetitive-element PCR as rapid alternative to IS6110fingerprinting for epidemiological studies of tuberculosis. J Clin Microbiol. 1998;36:1122-1124

15. Smittipat N. Three-year population-based evaluation of standardized Mycobacterial Interspersed Repetitive Unit-Variable Number of Tandem Repeat typing of Mycobacterium tuberculosis.JCM. 2005; 43:5034-5043.

16. Skuce RA, McCorry TP, McCarroll JF, Roring SM, Scott AN, Brittain D, Hughes S, R. Hewinson G, Neill S. Discrimination of Mycobacterium tuberculosis complex bacteria using novel VNTR-PCR targets.Microbiology, 2002; 148: 519-528

17. Keshavjee S, Farmer PE. Tuberculosis, drugresistance, andthe history of modern medicine. New Engl J Med 2012; 367: 931-936
18. World HealthOrganization. Guidelines for the programmatic management of drug-resistan tuberculosis-2011 update. Available at:HTTP://WHQLIBDOC.W HO.INT/ PUBLICATIONS / 2011/9789241501583_ENG.PDF.

19. Jain A, Dixit P. Multidrug-resistant to extensively drug resistant tuberculosis: what is next? J Biosci 2008;33(4): 605-616.

20. Dheda K, Gumbo T, Maartens G, et al. The epidemiology, pathogenesis, transmission, diagnosis, andmanagement of multidrug-resistant, extensively drug-resistant, and incurable tuberculosis. LancetRespir Med 2017; 5: 291-360.

21. Durmaz R. Mycobacterium tuberculosis'de Direnç Sorunu. ANKEM Dergisi. 2005; 19 (2): $107-110$

22. Baylan O. Extensively Drug Resistant and Extremely Drug Resistant Tuberculosis Forms After Multi-Drug Resistant Tuberculosis: New Faces of the Old Disease derleme 2009. Türkiye Klinikleri.

23. Yolsal N, Malat G, Dişci R, Örkün M, Killçaslan Z. Türkiye’de Tüberküloz İlaçlarına Direnç Sorununun 1984-1989 ve 1990-1995 Yilları İçin Karșılaștırılması; Meta-Analiz. Klimik Dergisi. 1998; 11(1): 6-9.

24. WHO. Global tuberculosis report 2018. Geneva: World HealthOrganization, https://www. who.int/tb/publications/global_report/gtbr2018_main_text_28Feb2019.pdf?ua\%20=\%201

25. Türkiye'de Verem Savaș Raporu 2017. https:// hsgm. saglik. gov.tr / depo/ haberler /verem-savas-raporu-2016-2017/Turkiyede_Verem_Savasi_2017_Raporu.pdf

26. BasilMV, Nair D. Molecularepidemiology of tuberculosis: Opportunitiesechallenges in diseasecontrol.Indian J MedRes. 2017; 146(1): 11-14.

27. van Soolingen D, Hermans PW, de Haas PE, Soll DR, van Embden JD .Occurrence and stability of insertion sequences in Mycobacterium tuberculosis complex strains: evaluation of an insertion sequence-dependent DNA polymorphism as a tool in the epidemiology of tuberculosis. J Clin Microbiol 1991;29: 2578-2586.

28. Kamerbeek J, Schouls L, Kolk A, van Agterveld M, van Soolingen D, et al. Simultaneous detection and strain differentiation of Mycobacterium tuberculosis for diagnosis and epidemiology. J Clin Microbiol 1997; 35: 907-914.

29. Zozio T, Allix C, Gunal S, Saribas Z, Alp A, Durmaz R, Fauville M, Rastogi, N. Sola, C. Genotyping of Mycobacterium tuberculosis Clinical Isolates in Twocities of Turkey: Description of a New Family of Genotypes That is Phylogeographically Specific for Asia Minor. BMC Microbiology, 2005; 5-44

30. Durmaz R, Zozio T, Gunal S, Allix C, Dufaux MF, Rastogi N. Population-Based Molecular Epidemiological Study of Tuberculosis in Malatya, Turkey.Journal of Clinical Microbiology December 2007, p. 4027-4035, Vol. 45.

31. Gencer B, Shinnick TM. Molecular Genotyping of Mycobacterium tuberculosis Isolates from Turkey. Am. J Infec Dis, 2005;(1), 5-11. 